\title{
HUBUNGAN ARKUS PEDIS DENGAN KELUHAN NYERI PUNGGUNG BAWAH PADA PERAWAT RUMAH SAKIT ISLAM JAKARTA TAHUN 2019
}

\author{
THE RELATIONSHIP OF ARCUS PEDIS AND LOW BACK PAIN COMPLAINTS AMONG \\ NURSES IN JAKARTA ISLAMIC HOSPITAL IN 2019
}

\author{
$\underline{\text { Rusyda Ayusti Anumillah }}{ }^{1}$, Yuli Suciati ${ }^{2}$, Arman Yurisaldi Saleh ${ }^{3}$ \\ 1. Program Studi Kedokteran Program Sarjana, Fakultas Kedokteran UPN “Veteran” Jakarta \\ 2. Departemen Rehabilitasi Medik, Fakultas Kedokteran UPN "Veteran” Jakarta \\ 3. Departemen Saraf, Fakultas Kedokteran UPN "Veteran" Jakarta \\ Jl. RS Fatmawati, Pondok Labu, Jakarta Selatan 12450, Telp. (021)7656971 \\ E-mail :rusydaayusti@gmail.com
}

\begin{abstract}
ABSTRAK
Arcus longitudinalis medialis pedis merupakan lengkung telapak kaki yang secara normal berfungsi untuk mendistribusikan beban tubuh sehingga tubuh memiliki postur dan pergerakan yang lebih stabil. Pada keadaan abnormal, arkus pedis dapat terlalu datar (pes planus) ataupun terlalu tinggi (pes cavus). Kelainan pada arkus tersebut dapat mengakibatkan perubahan biomekanik dan menimbulkan efek kaskade pada sendi-sendi yang lebih proksimal sehingga dapat menimbulkan keluhan nyeri punggung bawah (NPB). NPB sendiri memiliki prevalensi yang cukup tinggi yaitu 15 45\%. Gejala ini dapat dipicu dan diperburuk oleh berbagai faktor, salah satunya adalah berdiri dan berjalan dalam waktu yang lama seperti tuntutan profesi perawat. Tujuan penelitian ini adalah mengetahui hubungan arcus pedis dengan keluhan NPB pada perawat Rumah Sakit Islam Jakarta Cempaka Putih (RSIJCP). Desain penelitian ini adalah analisis observasional dengan metode case-control menggunakan 41 responden sebagai sampel yang ditentukan dengan teknik proportional random sampling. Data dikumpulkan dengan menggunakan pengisian kuisioner untuk menilai keluhan NPB dan wet footprint test untuk menilai sudut arkus pedis. Hasil penelitian menunjukkan tidak terdapat hubungan yang signifikan antara arkus pedis dengan keluhan NPB pada perawat di RSIJCP pada Bulan November Tahun 2019 ( $p=$ 0,161; CI 95\% 0.820-3,023).
\end{abstract}

Kata Kunci: arcus pedis, pes planus, pes cavus, nyeri punggung bawah

\begin{abstract}
Arcus longitudinalis medialis pedis is the arch of the foot which normally functions to distribute the body's burden so that the body has a more stable posture and movement. Under abnormal circumstances, the arcus pedis may be too flat (pes planus) or too high (pes cavus). Abnormalities of the arch may cause biomechanical changes and a cascade effect on more proximal joints with subsequent complaints of low back pain (LBP). LBP itself has a fairly high prevalence of 15-45\%. These symptoms can be triggered and exacerbated by various factors, one of which is standing and walking for a long time as the nursing profession demands. The purpose of this study was to determine the relationship of arcus pedis with LBP complaints among nurses of Cempaka Putih Jakarta Islamic Hospital. The design of this study was observational analysis with a case-control method using 41 respondents as a sample determined by proportional random sampling technique. Data were collected by using questionnaires to assess LBP complaints and wet footprint tests to assess the arcus pedis angle. The results showed that there was no significant relationship between arcus pedis with LBP complaints among nurses of Cempaka Putih Jakarta Islamic Hospital in November 2019 ( $p=0.161$; 95\% CI 0.820-3.023).
\end{abstract}

Keywords: arcus pedis, pes planus, pes cavus, low back pain 


\section{PENDAHULUAN}

Kaki merupakan organ penting untuk aktivitas sehari-hari, yaitu berfungsi untuk mempertahankan postur tubuh dan berjalan. Telapak kaki sebagai bagian terbawah kaki terutama arcus longitudinalis medialis pedis secara normal berfungsi untuk mendistribusikan beban tubuh sehingga tubuh memiliki postur dan pergerakan yang lebih stabil. Arkus yang terlalu rendah (pes planus) ataupun terlalu tinggi (pes cavus) dapat memengaruhi fungsinya dan dapat menimbulkan berbagai masalah kesehatan. Berbagai penilaian dapat digunakan untuk mendeteksi kelainan ini, seperti arch index. ${ }^{1}$

Angka kejadian pes planus pada populasi dewasa sebesar $20 \%$, sedangkan angka kejadian pes cavus sebesar $10 \% .^{2,3}$ Angka tersebut sulit diperkirakan, terutama di Indonesia, karena penapisan yang masih minim, penderita masih dapat beraktivitas seperti biasa dan belum banyak mendapat perhatian dari masyarakat. Sehingga, seringkali terdiagnosis sebagai keluhan lebih lanjut berupa komplikasi seperti artritis atau perkapuran persendian. Beberapa gejala dapat timbul sebelum terjadinya komplikasi namun hal ini berbeda pada setiap individunya.

Gejala-gejala progresifitas kelainan arkus pedis seringkali timbul pada saat orang tersebut berdiri lama. ${ }^{4}$ Postur berdiri dalam waktu yang lama tersebut memaksa telapak kaki bersamaan dengan tulang-tulang, persendian dan otot-otot untuk terus-menerus menompang berat tubuh dan mempertahankan postur. Kelainan dari arkus pedis juga dapat mengakibatkan kelainan pada gait/pola berjalan seperti pada penelitian, yang menyatakan bahwa keadaan arkus pedis memengaruhi tekanan puncak dan gaya maksimal pada bagian lateral forefoot yang sangat signifikan pada pes planus. ${ }^{5}$ Oleh karena itu, berdiri dan berjalan mungkin memiliki hubungan dengan keadaan arkus pedis dan dapat menimbulkan progresifitas gejala. Beberapa gejala yang sering timbul pada pes planus adalah deformitas, nyeri sepanjang tendon musculus tibialis posterior, metatarsalgia, plantar facitis, keluhan pada sendi lutut, kesulitan berjalan, aktivitas fisik yang terbatas ataupun menurun, kelelahan saat berjalan jauh, kesulitan menyeimbangkan tubuh. ${ }^{2}$ Sedangkan pada pes cavus, gejala yang sering timbul adalah overload metatarsal dan lateral, nyeri tumit, kekakuan, sprain dan ketidakstabilan pergelangan kaki, nyeri saat menggunakan alas kaki karena gesekan ibu jari hingga ulserasi, plantar fasitis, achilles tendonitis dan shin splints. ${ }^{6}$

Nyeri pada punggung bawah merupakan salah satu keluhan muskuloskeletal yang sering ditemui. Menurut WHO, prevalensi NPB mencapai $15-45 \%$ di negara maju. ${ }^{7}$ Sedangkan di Indonesia, prevalensi NPB juga cukup tinggi yaitu sebesar $18 \% .^{8}$ Penyebab NPB sering kali tidak diketahui, namun penyebab yang paling sering ditemukan adalah spasm dan tonus otot, jarang disebabkan oleh kelainan spesifik seperti radikular, facet joint, sakroiliaka, nyeri diskogenik dan stenosis spinal. ${ }^{9}$

Tonus otot merupakan salah satu faktor terpenting terutama pada NPB non-spesifik. Tonus otot itu sendiri memiliki fungsi penting dalam mempertahankan postur dan bergerak. Dengan adanya kelainan struktural pada organ lain, dapat mengganggu fungsi fisiologisnya sehingga timbul berbagai manifestasi klinis. Seperti pada penelitian di Amerika ${ }^{10}$, yang menyatakan bahwa kelainan pada telapak kaki berupa nyeri tumit telapak kaki dapat mengganggu fungsi fisiologis punggung bawah sehingga meningkatkan prevalensi NPB pada populasi tersebut sebesar $12 \%$. Pada penelitian lainnya, deviasi pada pedis dan telapak kaki dapat memengaruhi gait, panjang tungkai karena deviasi, perubahan susunan tulang pelvis yang dapat memicu terjadinya nyeri punggung bawah. ${ }^{11}$ Deviasi yang diteliti pada penelitian tersebut dapat terjadi pada kelainan arkus pedis. Pada penelitian di $\operatorname{Iran}^{12}$, didapatkan hasil yang signifikan antara kejadian nyeri punggung bawah dengan bentuk arkus pedis $(p=0,02)$ tetapi tidak pada tipe sendi lutut $(p=0,54)$, rotasi tibia $(p=0,24)$ dan 
rotasi femur $(p=0,66)$. Perubahan posisi pada komponen tungkai bawah selain arkus pedis kurang berpengaruh pada penelitian tersebut. Namun kelainan arkus pedis dapat memengaruhi sendi-sendi yang lebih proksimal meliputi tibia, femur, pelvis hingga menimbulkan dampak/efek baik secara biomekanik maupun neurologis pada regio lumbosacral. ${ }^{12,11}$ Terdapat kesenjangan pada penelitian-penelitian tersebut melihat dari kelainan arkus pedis sebagai faktor tunggal.

Tingkat aktivitas setiap orang berbedabeda, sehingga manifestasi klinis dari penyakit ini juga seringkali berbeda intensitas, jenis, maupun onset kelainan tersebut. Berdasarkan Kementrian Kesehatan, aktivitas fisik dibagi menjadi aktivitas ringan, sedang dan berat. ${ }^{13}$ Atlet merupakan profesi yang telah banyak diteliti hubungannya dengan pes planus. ${ }^{14,15}$ Atlet merupakan profesi yang membutuhkan kerja otot dengan intensitas tinggi sehingga tergolong pada aktivitas fisik berat. Sedangkaan perawat, merupakan profesi yang menuntut kerja otot sedang jika dibandingkan dengan atlet dan tergolong pada aktivitas fisik sedang namun membutuhkan kerja otot dengan waktu yang relatif lama yang dituntut untuk berdiri dan berjalan dengan waktu yang lama. Sebagai contoh penelitian pada responden perawat di Pekanbaru Indonesia ${ }^{16}$, berdasarkan wawancara, perawat ruang OK pada Intalasi Bedah Sentral RSUD Arifin Achmad Riau dapat berdiri hingga 10 jam lamanya.

Perawat merupakan salah satu tenaga kesehatan yang penting dalam pelaksanaan pelayanan kesehatan, namun distribusi tenaga kesehatan dan perawat di Indonesia belum merata. Berdasarkan Badan PPSDM Kesehatan, Kementrian Kesehatan Republik Indonesia Tahun 2018, tenaga kesehatan di Jakarta berjumlah 107.182 orang, yang memasuki 5 besar tenaga kesehatan terbanyak bersama dengan Jawa Timur, Jawa Tengah, Jawa Barat dan Sumatra Utara. ${ }^{17}$ Menurut sumber tersebut, perawat merupakan tenaga kesehatan yang memiliki jumlah paling banyak diantara tenaga kesehatan lainnya. Di Jakarta, total perawat berjumlah 29.782 orang dengan perbandingan terhadap jumlah penduduknya mencapai 1:285. ${ }^{17}$ Rumah Sakit Islam Jakarta merupakan Rumah Sakit Umum Swasta kelas utama yang merupakan klasifikasi tertinggi rumah sakit swasta dengan jaringan-jaringan pada tanggal 10 November 1995 berdasarkan Surat Keputusan Menteri Kesehatan RI No.1142/MenKes/SK/II/1995. ${ }^{18}$ RSI juga merupakan salah satu rumah sakit yang rutin mengadakan pelatihan dan menempatkan karyawan yang sesuai dengan standar kompetensi DEPKES. ${ }^{18}$ Oleh karena itu, diharapkan pelayanan yang diberikan RSIJ telah berstandar nasional, termasuk di dalamnnya regulasi tenaga kesehatan perawat, dengan beban kerja yang proporsional yaitu beban kerja yang sesuai dengan kompetensinya sehingga keluhan NPB bukan diakibatkan beban kerja yang tidak proporsional.

\section{METODE PENELITIAN}

\section{Desain Penelitian}

Pengambilan data pada penelitian ini menggunakan pendekatan analisis observasional dengan desain penelitian casecontrol, yaitu membagi sampel perawat instalasi rawat inap, rawat jalan dan kamar bedah Rumah Sakit Islam Jakarta menjadi kelompok yang memiliki keluhan nyeri punggung bawah dan yang tidak memiliki keluhan nyeri punggung bawah. Kemudian setiap subjek diukur arkus pedisnya untuk menentukan apakah subjek tersebut tergolong dalam normal feet arch, flat feet dan high arch.

\section{Populasi dan Sampel}

Populasi penelitian ini adalah seluruh perawat instalasi rawat inap, rawat jalan dan kamar bedah Rumah Sakit Islam Jakarta pada tahun 2019.

Sampel penelitian ini adalah perawat instalasi rawat inap, rawat jalan dan kamar bedah Rumah Sakit Islam Jakarta yang memiliki yang tidak memiliki keluhan NPB yang memenuhi kriteria inklusi masa kerja lebih dari enam bulan. 


\section{Pengumpulan Data}

Penelitian ini menggunakan sumber data primer, yaitu mengambil data langsung pada sampel melalui kuisioner dan pemeriksaan fisik pada perawat Rumah Sakit Islam Jakarta Tahun 2019.

\section{Analisis Data}

Pengolahan data kategorik secara univariat dilakukan untuk mengetahui proporsi kelompok pada variabel variasi arkus pedis dan keluhan NPB. Analisis bivariat untuk menilai hubungan arkus pedis dengan keluhan NPB dilakukan dengan uji Chi-square, atau uji alternatifnya yaitu uji fisher.

\section{HASIL PENELITIAN}

\section{Karakteristik Responden}

Distribusi responden menurut karakteristik usia, jenis kelamin, instalasi tempat bekerja dan karakteristik waktu kerja tercantum pada Error! Reference source not found.. Responden terbanyak berdasarkan data tersebut adalah kelompok usia dewasa awal, yaitu sebanyak 16 responden (39\%) dengan rentang usia 26-35 tahun. Jenis kelamin responden terbanyak adalah wanita, yaitu sebanyak 36 responden (87,8\%). Responden bertugas di beberapa instalasi, setiap instalasi diwakili berkisar antara 3-6 responden (7,3-12,2\%). Berdasarkan karakteristik waktu kerja, sebagian besar responden bertugas selama $\geq 8$ jam $(63,4 \%)$, dengan durasi berdiri $\geq 2$ jam $(51,2 \%)$ dan durasi berjalan $\geq 20$ menit $(65,9 \%)$.

Tabel 1. Karakteristik Responden

\begin{tabular}{|c|c|c|c|}
\hline No. & Karakteristik & $\underline{\underline{n}}$ & $\%$ \\
\hline \multirow[t]{6}{*}{1} & Usia & & \\
\hline & 17-25 tahun & 8 & 19,5 \\
\hline & 26-35 tahun & 16 & 39 \\
\hline & $36-45$ tahun & 5 & 12,2 \\
\hline & 46-55 tahun & 12 & 29,3 \\
\hline & Total & $\underline{41}$ & 100 \\
\hline \multirow[t]{4}{*}{2} & Jenis Kelamin & & \\
\hline & Perempuan & 36 & 87,8 \\
\hline & Laki-laki & 5 & 12,2 \\
\hline & Total & 41 & 100 \\
\hline
\end{tabular}

\begin{tabular}{|c|c|c|}
\hline Poliklinik & 3 & 7,3 \\
\hline HD & 4 & 9,8 \\
\hline IGD & 5 & 12,2 \\
\hline Melati & 6 & 14,6 \\
\hline Zam-zam & 4 & 9,8 \\
\hline Badar & 6 & 14,6 \\
\hline Marwah & 4 & 9,8 \\
\hline ICU & 4 & 9,8 \\
\hline Kamar Bedah & 5 & 12,2 \\
\hline Total & $\underline{41}$ & 100 \\
\hline \multirow{2}{*}{\multicolumn{3}{|c|}{$\begin{array}{l}\text { Karakteristik Waktu Kerja } \\
\text { Durasi Kerja }\end{array}$}} \\
\hline & & \\
\hline$<8$ jam & 15 & 36,6 \\
\hline$\geq 8$ jam & 26 & 63,4 \\
\hline Total & 41 & 100 \\
\hline \multicolumn{3}{|l|}{ Durasi Berdiri } \\
\hline$<2$ jam & 20 & 48,8 \\
\hline$\geq 2$ jam & 21 & 51,2 \\
\hline Total & 41 & 100 \\
\hline \multicolumn{3}{|l|}{ Durasi Berjalan } \\
\hline$<20$ menit & 14 & 34,1 \\
\hline$\geq 20$ menit & 27 & 65,9 \\
\hline Total & $\underline{41}$ & 100 \\
\hline
\end{tabular}

\section{Hasil Analisis Univariat}

Hasil analisis univariat penelitian di RS Islam Jakarta tahun 2019 dapat tercantum pada Error! Reference source not found.. Berdasarkan data tersebut, sebagian besar responden memiliki arkus pedis normal, yaitu sebanyak 20 responden $(48,8 \%)$, diikuti dengan pes cavus sebanyak 17 responden (41,5\%) dan terakhir pes planus sebanyak 4 responden $(9,8 \%)$. Sedangkan untuk distribusi keluhan NPB, responden yang memiliki dan tidak memiliki keluhan NPB hampir sama banyak, yaitu 21 responden $(51,2 \%)$ memiliki keluhan NPB dan 20 responden $(48,8 \%)$ tidak memiliki keluhan NPB.

Tabel 2. Variasi Anatomis Arkus Pedis dan Keluhan Nyeri Punggung Bawah

\begin{tabular}{|c|c|c|c|}
\hline No & Karakteristik & $\underline{n}$ & $\%$ \\
\hline \multirow[t]{5}{*}{1} & Arkus Pedis & & \\
\hline & Pes Cavus & 17 & 41,5 \\
\hline & Arkus Normal & 20 & 48,8 \\
\hline & Pes Planus & 4 & 9,8 \\
\hline & Total & 41 & 100 \\
\hline \multirow[t]{3}{*}{2} & Keluhan NPB & & \\
\hline & NPB & 21 & 51,2 \\
\hline & Tidak NPB & 20 & $\underline{48,8}$ \\
\hline
\end{tabular}

Hasil Analisis Bivariat 
Hubungan Arkus Pedis dengan Keluhan Nyeri Punggung Bawah dengan Perawat RS Islam Jakarta tercantum pada Error! Reference source not found.. Data menunjukkan bahwa pada kelompok responden dengan keluhan NPB, didapatkan proporsi variasi anatomis terbanyak adalah pes cavus, yaitu sebanyak 10 responden $(47,6 \%)$. Sedangkan pada kelompok responden tanpa keluhan NPB, didapatkan proporsi variasi anatomis terbanyak adalah arkus normal, yaitu sebanyak 12 responden $(60 \%)$.

Berdasarkan hasil analisis pada Error! Reference source not found., $P$-value yang didapatkan dari uji tersebut adalah 0,161 ( $\mathrm{p}>$ 0,05) dengan CI 95\% (0.820-3,023), sehingga secara statistik tidak didapatkan bukti yang cukup untuk menolak hipotesis pertama, yaitu tidak terdapat hubungan yang signifikan antara arkus pedis dengan keluhan NPB pada perawat di Rumah Sakit Islam Cempaka Putih pada Bulan November Tahun 2019. Sedangkan nilai odd ratio pada Error! Reference source not found. menyatakan bahwa kelainan arkus pedis dapat meningkatakan risiko terjadinya keluhan NPB sebesar 2,4 kali jika dibandingkan dengan arkus normal. Berdasarkan odd ratio setiap tipe variasi anatomis arkus pedis abnormal, didapatkan peningkatan risiko terjadinya keluhan NPB pada pes planus lebih besar yaitu 4,5 kali jika dibandingkan dengan pes cavus yaitu 2,1 kali.

Tabel 4. Hubungan Stres Setiap Domain Stresor dengan Kecenderungan Gangguan Mental Emosional

\begin{tabular}{|c|c|c|c|c|c|c|}
\hline \multirow{3}{*}{$\begin{array}{c}\text { Arkus } \\
\text { Pedis } \\
\text { Normal }\end{array}$} & \multicolumn{4}{|c|}{ Keluhan NPB } & \multirow{3}{*}{ value } & \multirow{3}{*}{ OR } \\
\hline & Ya & \multicolumn{2}{|c|}{ Tidak } & Total & & \\
\hline & $\mathbf{N} \%$ & $\mathbf{N}$ & $\%$ & $\mathrm{~N} \%$ & & \\
\hline Tidak & 1361,9 & 8 & 402 & 151,2 & & \\
\hline $\begin{array}{l}\text { Ya } \\
\text { Total }\end{array}$ & $\begin{array}{cl}8 & 38,1 \\
21 & 100\end{array}$ & $\begin{array}{c}12 \\
20\end{array}$ & $\begin{array}{r}60 \\
100\end{array}$ & $\begin{array}{cc}20 & 48,8 \\
37 & 100\end{array}$ & 0,161 & 2,438 \\
\hline
\end{tabular}

\section{PEMBAHASAN}

Hasil analisis univariat pada variabel variasi anatomis arkus pedis responden perawat di Rumah Sakit Islam Cempaka Putih pada Bulan November Tahun 2019 merupakan gambaran distribusi frekuensi yang terdapat pada Error! Reference source not found. Dari hasil analisis tersebut, di dapatkan jumlah terbanyak adalah arkus pedis normal sebanyak 20 responden $(48,8 \%)$. Sebagian besar populasi memiliki arkus pedis normal, hanya sebagian kecil yang memiliki kelainan arkus pedis. ${ }^{2,3}$

Pada penelitian ini, didapatkan sebanyak 17 responden $(41,5 \%)$ yang memiliki variasi anatomis pes cavus. Hal tersebut tidak sesuai dengan epidemiologi pes cavus yang hanya berkisar di angka $10 \%$ dari populasi. ${ }^{3}$ Angka kejadian pes cavus pada analisis penelitian ini terlampau tinggi. Penyebab pes cavus antara lain adalah penyakit neurologis dan neurologis yang mendasari, trauma serta idiopatik. ${ }^{19}$ Pada penelitian ini kelainan-kelainan yang mendasari dan trauma telah disingkirkan. Sehingga tingginya angka kejadian pes cavus dapat diakibatkan karena idiopatik/familial yang tidak tersebar secara merata pada populasi perawat RSIJCP. Sedangkan angka kejadian pes planus pada analisis penelitian ini sebanyak 4 responden $(9,8 \%)$. Hal tersebut tidak sesuai dengan epidemiologi pes planus yang berkisar di angka $20 \%$ dari populasi. ${ }^{2}$ Pada penelitian ini angka kejadian pes planus sangat rendah. Penyebab pes planus antara lain bawaan/fisiologis; dan didapat seperti trauma, deformitas, degeneratif dan obesitas. ${ }^{2}$ Penyebab terbanyak pes planus berupa kelainan muskuloskeletal lain, trauma dan obesitas telah dieksklusikan pada penelitian ini, sehingga distribusi pes planus tidak merata dan menyisakan hanya sedikit responden dengan pes planus pada penelitian ini.

Hasil analisis univaiat pada variabel NPB responden perawat di Rumah Sakit Islam Cempaka Putih pada Bulan November Tahun 2019 merupakan gambaran distribusi frekuensi yang terdapat pada Error! Reference source not found.. Pada hasil analisis tersebut didapatkan proporsi yang hampir sama antara responden yang memiliki keluhan NPB sebanyak 21 responden $(51,2 \%)$ dan responden yang tidak memiliki keluhan NPB sebanyak 20 
responden (48,8\%). Menurut Kementrian Kesehatan Republik Indonesia Tahun 2018, prevalensi NPB di Indonesia juga cukup tinggi yaitu sebesar $18 \% .{ }^{8}$ Sedangkan pada penelitian ini keluhan NPB mecapai hampir setengah dari jumlah sampel. Hal ini sama seperti pendapat di Turkey ${ }^{20}$ yang menyatakan bahwa prevalensi NPB pada perawat berkisar antara 40-97,9\%. Penelitian ini melingkupi populasi perawat yang memiliki aktivitas fisik tinggi seperti yang tergambar pada Error! Reference source not found. Hal ini sesuai dengan data yang ada, yaitu angka kejadian NPB meningkat seiring dengan usia dan mencapai puncak pada dekade pertengahan hingga dekade keempat kehidupan menurut Kementrian Kesehatan Republik Indonesia dan pada usia 33-55 tahun menurut WHO. ${ }^{8,7}$ Usia tersebut tercakup dalam populasi ini, seperti pada Error! Reference source not found. responden terbanyak berusia 46-55 tahun. Aktivitas fisik secara spesifik pada perawat, terutama saat bertugas seperti berjalan dan berdiri dalam waktu yang lama, posisi tertentu dalam merawat pasien, bahkan memindahkan dan mengangkat pasien dapat menjadi faktor yang meningkatkan stress pada regio lumbosacral. Aktivitas-aktivitas tersebut dapat memengaruhi keluhan NPB baik dari segi lamanya pajanan ataupun besarnya stress pada punggung bawah. Aktivitas fisik pada perawat saat melakukan tugasnya dapat meningkatkan keluhan NPB. ${ }^{21,20}$ Hal tersebut dapat menyebabkan populasi pada penelitian ini lebih banyak individu dengan keluhan NPB jika dibandingkan dengan prevalensi umum NPB karena cenderung terkumpul pada populasi karena isolasi populasi spesifik, yaitu perawat.

Hasil analisis bivariat mengenai hubungan arkus pedis dengan keluhan NPB pada responden perawat di Rumah Sakit Islam Cempaka Putih pada Bulan November Tahun 2019 menggunakan uji chi-square terdapat pada Error! Reference source not found., didapatkan $p$-value sebesar $0,161(\mathrm{p}>0,05)$ dengan CI 95\% (0.820-3,023). Hasil tersebut menunjukkan bahwa secara statistik tidak didapatkan bukti yang cukup untuk menolak hipotesis pertama, yaitu tidak terdapat perbedaan variasi anatomis arkus pedis yang signifikan antara kelompok dengan dan tanpa keluhan NPB pada perawat di Rumah Sakit Islam Cempaka Putih pada Bulan November Tahun 2019. Sehingga pada penelitian ini hubungan antara arkus pedis dengan keluhan NPB pada populasi perawat di Rumah Sakit Islam Cempaka Putih pada Bulan November Tahun 2019 tidak dapat disimpulkan.

Terdapat beberapa faktor yang dapat menjadi alasan hubungan kedua variabel tidak dapat digambarkan, yaitu effect size, jumlah sampel dan variabilitas sampel. Berdasarkan hasil perhitungan, didapatkan nilai Phi $\varphi$ 0,219 yang menandakan bahwa effect size arkus pedis terhadap keluhan NPB lemah. Menurut rumus perhitungan $P h i \quad \varphi$, hasil yang didapatkan dipengaruhi oleh hasil $p$ value serta besar dan variabilitas sampel. Effect size yang rendah dapat mengakibatkan pada penelitian ini bukti yang didapatkan tidak cukup untuk menggambarkan hubungan antara variabelvariabel tersebut. Faktor independen lain telah dieksklusikan juga dapat memengaruhi, sehingga effect size yang kecil dapat diakibatkan oleh banyaknya faktor lain yang dapat secara langsung maupun secara tidak langsung berinteraksi dengan variabel arkus pedis untuk memengaruhi kejadian keluhan NPB pada populasi ini. Dengan tersingkirnya faktor-faktor tersebut, dan arkus pedis menjadi faktor tunggal, maka efek yang dihasilkan dapat menjadi sangat kecil. Salahsatu faktor yang dapat berinteraksi dengan variabel arkus pedis adalah aktivitas responden dalam melaksanakan tugas profesinya, yaitu faktor yang menjadi fokus pada populasi penelitian ini. Terlihat pada Error! Reference source not found., waktu dan durasi karakteristik aktivitas dalam bekerja serta bagian kerja pada sampel bervariasi. Gejala-gejala progresifitas kelainan arkus pedis dapat dipengaruhi oleh berdiri dalam waktu yang lama dan perubahan pola jalan. ${ }^{4,11,12}$ Namun karakteristik responden pada penelitian ini digambarkan secara umum dan tidak memperhatikan efek 
lebih besar yang dapat ditimbulkan dari variabel yang berinteraksi dengan variabel arkus pedis.

Timbulnya keluhan NPB pada perawat juga dapat dipengaruhi secara langsung oleh faktor lain yang tidak berinteraksi dengan variabel arkus pedis. Berdasarkan analisis univariat pada Error! Reference source not found., didapatkan perawat terbanyak dengan arkus normal, sedangan keluhan NPB ditemukan lebih dari setengah populasi. Berdasarkan keadaan pada sampel tersebut, kejadian keluhan NPB dapat diakibatkan oleh faktor lain yang tidak melibatkan arkus pedis. Pada populasi perawat, NPB dapat meningkat karena IMT (indeks massa tubuh) yang tinggi, banyaknya kehamilan, artritis, keadaan fisik yang kurang baik, postur yang kurang baik saat bertugas, penempatan alat dan tempat kerja yang tidak baik. ${ }^{21}$ Pada penelitian ini, obese, kehamilan dan artritis telah dieksklusikan, sehingga faktor pekerjaan seperti postur, keadaan fisik dan lingkungan dapat memiliki pengaruh pada keluhan NPB. Aktivitas mengangkat beban berat seperti pemindahan dan pengangkutan pasien pada saat perawatan merupakan faktor utama terjadinya keluhan NPB pada perawat. ${ }^{20}$

Berdasarkan observasi pada populasi perawat RSIJCP, perawat ruang rawat inap seperti Ruang Melati, Zam-zam, Badar dan Marwah Atas memiliki tugas yang didominasi dengan berjalan ke setiap ruangan rawat inap dan berdiri dalam mengontrol dan memberikan perawatan pada pasien. Sedangkan pada pelayanan rawat jalan seperti Ruang Poli dan Hemodialisa, tugas perawat didominasi oleh berdiri saat memberikan pelayanan medis dan duduk. Pada Ruang IGD dan ICU tugas perawat bervariasi, dari kasus ringan yaitu berjalan dan berdiri saat memberikan pelayanan, hingga mengangkat, meggeser, menarik dan mendorong pasien saat memberikan pelayanan medis. Hal ini juga sesuai dengan hasil wawancara pada responden $\mathrm{R}$ dan $\mathrm{Y}$ yang menyatakan bahwa keluhan NPB sering timbul setelah mendorong dan mengangkat pasien terutama jika posisi tubuh tidak benar dan mengurus pasien yang meninggal karena tubuh pasien menjadi lebih berat. Sedangkan pada Ruangan Operasi, tugas perawat didominasi dengan berdiri pada posisi dan kegiatan tertentu dalam waktu yang lama. Hal tersebut sesuai dengan tugas perawat operasi pada umumnya, sebagai contoh penelitian pada responden perawat di Pekanbaru Indonesia ${ }^{16}$, berdasarkan wawancara, perawat ruang OK pada Intalasi Bedah Sentral RSUD Arifin Achmad Riau dapat berdiri hingga 10 jam lamanya. Berdasakan wawancara pada responden, untuk peerawat anastesi lebih banyak berdiri dan keliling memberikan dan memstikan anastesi pada setiap ruangan operasi. Sedangkan menurut responden perawat asisten operasi YN berdiri pada saat operasi bisa berjam-jam lamanya, bergantung besar atau kecilnya operasi yang berjalan. Berdasarkan uraian tersebut, keluhan NPB pada populasi ini dapat sangat dipengaruhi oleh karakteristik beban kerja perawat yang berbeda-beda pada setiap bagiannya.

Secara statistik tidak terdapat hubungan yang bermakna antara variabel arkus pedis dan keluhan NPB pada populasi perawat di Rumah Sakit Islam Cempaka Putih pada Bulan November Tahun 2019. Sedangkan sampel pada penelitian ini memiliki nilai odd ratio pada Error! Reference source not found. yang menyatakan bahwa kelainan arkus pedis dapat meningkatakan risiko terjadinya keluhan NPB sebesar 2,4 kali jika dibandingkan dengan arkus normal pada responden perawat di Rumah Sakit Islam Cempaka Putih pada Bulan November Tahun 2019. Angka tersebut menunjukkan bahwa arkus pedis memiliki pengaruh klinis terhadap keluhan NPB, terutama pada populasi perawat dengan aktivitas kerja lebih banyak berdiri dan berjalan. Fungsi dinamis arkus pedis seperti berjalan lebih berpengaruh terhadap regio lumbosacral jika dibandingkan dengan fungsi statisnya seperti berdiri. ${ }^{22}$ Pengaruh klinis arkus pedis dangan keluhan NPB dapat dijelaskan dengan mekanisme posturalstruktural-biomekanikal. ${ }^{23}$ Hal tersebut 
diperkuat dengan bukti bahwa kelainan pada arkus pedis dapat memengaruhi keluhan NPB dengan cara merubah pola jalan, panjang tungkai karena deviasi, perubahan susunan tulang pelvis. ${ }^{11,12}$ Keadaan-keadaan tersebut dapat mengakibatkan perubahan biomekanik pada punggung bawah, sehingga dapat meningkatkan risiko keluhan NPB. Perataan atau kekakuan arkus pedis dapat mengakibatkan gaya berat tubuh saat menapak tidak tersebar secara proporsional. Jika fungsi tungkai bawah terganggu, termasuk di dalamnya fungsi shock-absorbing pada kaki, akan menyebabkan biomekanik regio lumbalis juga akan terganggu. ${ }^{22,10}$ Perubahan yang dapat mengganggu biomekanik tersebut antara lain adalah perubahan posisi/kedudukan tulang pelvis dan aktivitas $m$. erector spinae dan $\mathrm{mm}$. glutealis. ${ }^{22}$

Secara umum, kelainan pada arkus pedis dapat meningkatkan risiko terjadinya keluhan NPB sebanyak 2,4 kali pada responden perawat di Rumah Sakit Islam Cempaka Putih pada Bulan November Tahun 2019. Namun kelainan arkus pedis tersebut terdiri atas dua kondisi, yaitu pes cavus dan pes planus. Oleh karena itu, analisis lebih lanjut dilakukan untuk melihat peningkatan risiko terjadinya keluhan NPB pada masing-masing kondisi kelainan arkus pedis. Berdasarkan hasil analisis yang didapatkan, tipe arkus pedis pes cavus dapat meningkatkan risiko terjadinya keluhan NPB pada responden perawat di Rumah Sakit Islam Cempaka Putih pada Bulan November Tahun 2019 sebesar 2,1 kali. Sedangkan, peningkatan risiko terjadinya keluhan NPB pada pes planus sebesar 4,5 kali. Maka dapat disimpulkan bahwa peningkatan risiko terjadinya keluhan NPB pada pes planus lebih besar dibandingkan dengan pes cavus.

Gaya reaksi vertikal bumi/vertical ground reaction force (VGRF) pada pes planus VGRF lebih tinggi pada tulang-tulang tarsal, sedangkan pada pes cavus VGRF lebih tinggi pada tulang talus dan tulang phalanges pertama. ${ }^{24}$ Selain itu, luas permukaan kontak pes planus lebih besar jika dibandingkan dengan pes cavus yang mengakibatkan pes planus lebih tidak stabil dan membutuhkan lebih banyak energi saat berjalan sehingga lebih mudah lelah jika dibandingkan dengan pes cavus. $^{24}$ Ketidakstabilan dan pengaruh biomekanik tersebut dapat disalurkan dan dapat mengganggu dan berdampak pada sendisendi yang lebih proksimal. Momen gaya yang didapatkan pada pes planus lebih besar menggunakan pengukuran dengan alat optoelectronic system (Motion Analysis System) pada sendi panggul, lutut dan tumit. ${ }^{25}$ Berdasarkan penelitian-penelitian tersebut didapatkan perbedaan keadaan antara pes planus dengan pes cavus berupa luas permukaan dan VGRF yang dapat menimbulkan perbedaan pula pada efek gaya yang diterima oleh sendi-sendi yang lebih proksimal yang digambarkan melalui momen gaya pada panggul (hip), lutut (knee) dan tumit (ankle).

Besarnya efek pada pes planus berdasarkan hasil penelitian pada penjelasan di atas dan OR pada penelitian ini didukung oleh penelitian di Inggris ${ }^{25}$ yang menyatakan bahwa NPB merupakan salah satu komplikasi yang dapat terjadi pada penderita pes planus. Sedangkan belum ada penelitian yang menyatakan bahwa NPB dapat menjadi komplikasi dari kadaan pes cavus. Dari hasil tersebut, dapat disimpulkan bahwa pes planus memiliki dampak yang lebih bersar terhadap perubahan biomekanika pada regio lumbosacral. Faktor yang berperan penting adalah posisi pedis yang hiperpronasi. Pada fase berjalan menompang dengan arkus pedis normal, posisi pedis menjadi pronasi dan arkus pedis akan mendatar yang berfungsi sebagai penyalur momen gaya atau torsi untuk mengabsorpsi rotasi pada tungkai, serta mempersiapkan tubuh untuk menerima gaya reaksi dari kontak yang diciptakan. ${ }^{11}$ Terdapat interaksi kinematik sendi pada awal fase menompang (stance phase), yaitu saat terjadi eversi tulang calcaneus, adduksi tulang talus dan fleksi plantar pedis, maka tulang talus mengalami translasi inferomedial yang mengakibatkan rotasi internal tulang tibia kemudian tulang femur, dan pada akhirnya 
menyebabkan pergeseran kemiringan pelvis ke arah anterior karena adanya jaringan ikat penghubung yang erat. ${ }^{22}$ Apabila pronasi berlebihan, atau yang sering disebut dengan keadaan hiperpronasi, gerakan kompensasi dari sendi-sendi proksimal akan meningkat dan besarnya stress yang diterima pada regio lumbo-pelvic akan betambah besar. Keadaan hiperpronasi ini merupakan efek/manifestasi klinis dari kelainan arkus pedis tipe pes planus. Hal tersebut terjadi karena hiperpronasi dapat mengakibatkan rotasi internal berlebihan yang akan mengakibatkan over-rotasi pada pelvis yang dapat menggeser kemiringan ke anterior sebanyak $10^{\circ}$ dari pusat tubuh dan disfungsi sendi sacroiliaca. ${ }^{12,11}$ Oleh karena kemiringan tersebut, maka akan terjadi perubahan kurvatura regio lumbaris dan susunan lumbopelvis. Seperti penelitian di $\operatorname{Iran}^{26}$, yang menunjukkan hasil bahwa pronasi pedis sebesar $10^{\circ}, 15^{\circ}, 20^{\circ}$ akan mengakibatkan peningkatan lumbar lordosis sebesar $1,9^{\circ}, 2,2^{\circ}$, $2,4^{\circ}$. pergeseran kurvatura pada regio lumbal dapat menggeser pusat berat badan/gravitasi (center of mass based on center of gravity) ${ }^{27}$. Perubahan kurvatura dan susunan tersebut dapat mengakibatkan stress dan ketidakseimbangan otot-otot yang berada pada regio lumbosacral. Ketidakseimbangan yang terjadi akan dikompensasi dengan meningkatkan tonus oto-otot regio lumbosacral sehingga tercapai keseimbangan biomekanik. Namun pada pes planus kompensasi tersebut terjadi secara terusmenerus dan berkepanjangan sehingga dapat mengakibatkan ketegangan/strain otot-otot yang terlibat. Otot-otot yang menjadi tegang antara lain $m$. iliopsoas, $m$. erector spinae, $m$. piriformis dan $m$. gluteus maximus, yang dapat berlanjut ke arah perubahan susunan/kurvatura vertebra dan pergeseran posisi art. sacroiliac $^{12}$.

Individu dengan kelainan arkus pedis berupa pes cavus, dampak/efek neurologis yang diterima oleh regio lumboscral lebih besar dibandingkan dengan efek biomekanik yang diterima pada bagian tersebut. ${ }^{12}$ Dampak/efek neurologis ini bersifat dinamis terutama saat berjalan, tidak secara terus menerus seperti efek hiperpronasi pada individu dengan kelainan arkus pedis berupa pes planus. Saat fase berjalan terjadi perubahan dari tumit sebagai tumpuan berubah menjadi forefoot sebagai tumpuan dan tumit terangkat, dampak neurologis berkurang pada kolumna vertebralis ${ }^{12}$. Oleh karena fungsi dinamis arkus pedis lebih berpengaruh terhadap keluhan NPB, hiperpronasi pada pes planus memiliki efek yang kuat dan dampak neurologis pada pes cavus saat fase tertentu berjalan berkurang, maka peningkatan risiko terjadinya keluhan NPB sebanding dengan paparan perubahan yang abnormal pada regio lumbosacral, yaitu lebih besar pada keadaan pes planus jika dibandingkan dengan pes cavus.

\section{KESIMPULAN}

Berdasarkan hasil dan pembahasan yang sudah dipaparkan, dapat ditarik kesimpulan bahwa variasi anatomis arkus pedis responden perawat RS Islam Jakarta tsebanyak adalah arkus pedis normal sebanyak 20 responden $(48,8 \%)$, diikuti dengan pes cavus dan terakhir pes planus. Sedangkan angka kejadian keluhan NPB pada responden tersebut mencapai 51,2\% yaitu 21 responden. yang memiliki arkus pedis pes planus. Berdasarkan hasil data yang diperoleh, dari 41 responden terdapat sebanyak 20 responden $(48,8 \%)$ yang memiliki arkus pedis normal, 17 responden $(41,5 \%)$ yang memiliki arkus pedis pes cavus dan 4 responden $(9,8 \%)$ yang memiliki arkus pedis pes planus.

Secara statistik dapat disimpulkan bahwa tidak terdapat hubungan yang signifikan antara arkus pedis dengan keluhan NPB. Namun, kelainan arkus pedis meningkatkan risiko terjadinya keluhan NPB sebanyak 2,4 kali jika dibandingkan dengan arkus pedis normal. Peningkatan risiko terjadinya keluhan NPB pada pes planus (4,5 kali) lebih besar daripada pes cavus (2,1 kali).

\section{DAFTAR PUSTAKA}


1. Shariff SM, Manaharan T, Shariff AA, Mmerican AF. Evaluation of Foot Arch in Adult Women : Comparison between Five Different Footprint Parameters.

Sains Malaysiana [Internet]. 2017;46(10):1839-48. Available from: http://dx.doi.org/10.17576/jsm-20174610-22\%0AEvaluation

2. Lowth M. Pes Planus. In: Orthopaedic and Sports Medicine [Internet]. 2016 [cited 2019 May 3]. Available from: https://patient.info/doctor/pes-planusflat-feet

3. Piazza S, Ricci G, Caldarazzo Ienco E, Carlesi C, Volpi L, Siciliano G, et al. Pes cavus and hereditary neuropathies: when a relationship should be suspected. J Orthop Traumatol. 2010;11(4):195-201.

4. Hunter G. Pes Planus ( Flat Foot ). In: The Workplace Safety and Insurance Appeals Tribunal [Internet]. 2002 [cited 2019 Jul 27]. Available from: http://www.wsiat.on.ca/english/mlo/pes _planus.htm

5. Buldt AK, Forghany S, Landorf KB, Levinger P, Murley GS, Menz HB. Gait \& Posture Foot Posture is Associated with Plantar Pressure During Gait : A Comparison of Normal, Planus and Cavus feet. Gait Posture [Internet]. 2018;62:235-40. Available from: https://doi.org/10.1016/j.gaitpost.2018. 03.005

6. Physiopedia contributors. Pes cavus. In: Physiopedia [Internet]. 2019 [cited 2019 Jul 25]. Available from: https://www.physiopedia.com/Pes_cavus

7. WHO. Low Back Pain [Internet]. Vol. 24, Priority Diseases and Reasons for Inclusion. 2010 [cited 2019 Jul 27]. p. 8-10. Available from: https://www.who.int/medicines/areas/p
riority_medicines/Ch6_24LBP.pdf

8. Kesehatan Masyarakat Kementrian Kesehatan RI. Low Back Pain (LBP). Jakarta: Kementrian Kesehatan RI; 2018.

9. Allegri M, Montella S, Salici F, Valente A, Marchesini M, Compagnone C, et al. Mechanisms of low back pain. F1000Research. 2016;5:1-11.

10. Mcclinton AS, Weber CF. Low Back Pain and Disability in Individuals with Plantar Heel Pain. Foot [Internet]. 2017; Available from: https://doi.org/10.1016/j.foot.2017.09.0 03

11. O'Leary CB, Cahill CR, Robinson AW, Barnes MJ, Hong J. A systematic review: The effects of podiatrical deviations on nonspecific chronic low back pain. J Back Musculoskelet Rehabil. 2013;26(2):117-23.

12. Balouchy R. Comparative Analysis of Lower Limb Alignments in Healthy Subjects and Subjects with Back Pain. Ann Appl Sport Sci. 2015;3(2):33-42.

13. Ratnawati I. Pemenuhan Kecukupan Gizi Bagi Pekerja [Internet]. Direktorat Jendral Kesehatan Masyarakat Kementrian Kesehatan. 2011 [cited 2019 Jul 15]. Available from: www.kesmas.kemkes.go.id/portal/kont en/ rilis-berita/021411-pemenuhankecukupan-gizi-bagi-pekerja

14. Ridjal AI. Perbandingan Kekuatan Otot Tungkai Antara Normal Foot dan Flat Foot pada Atlet Basket. Skripsi Fakultas Kedokteran, Universitas Hasanuddin; 2016.

15. Hermawan I, Tarsono T. Hubungan Bentuk Telapak Kaki, Panjang Tungkai Dengan Daya Ledak Otot Tungkai Terhadap Atlet Kids Athletics Putri 11- 
14 Tahun Rawamangun. J Phys Educ Heal Recreat. 2018;1(2):25.

16. Ariani FL. Hubungan Lama Berdiri dengan Kejadian Varises pada Perawat di Ruang OK Instalasi Bedah Sentral RSUD Arifin Achmad. Skripsi Ilmu Keperawatan, Universitas Riau Pekanbaru; 2012.

17. Badan PPSDM Kesehatan. Data Tenaga Kesehatan. Jakarta: Kementrian Kesehatan RI; 2018.

18. Fitri R. Gambaran Kompetensi Perawat ICU dan HCU serta Hubungannya dengan Pendidikan, Pelatihan dan Pengalaman di Rumah Sakit Islam Jakarta Cempaka Putih Tahun 2009. Skripsi Fakultas Kesehatan Masyarakat, Universitas Indonesia; 2009.

19. Ball T, Butler M, Parsons S. Pes Cavus - Not Just a Clinical Sign. Acnr [Internet]. 2013;12(6):16-9. Available from: https://www.acnr.co.uk/wpcontent/uploads/2017/07/pes-cavusarticle-2.pdf

20. Tosunoz IK, Oztunc G. Low Back Pain in Nurses. Int $\mathbf{J}$ Caring Sci [Internet]. 2017;10(3):1728-32. Available from: http://internationaljournalofcaringscien ces.org/docs/70_ipek_special_10_3.pdf

21. Boughattas W, Maalel O El, Maoua M, Bougmiza I, Kalboussi H, Brahem A, et al. Low Back Pain among Nurses: Prevalence, and Occupational Risk Factors. Occup Dis Environ Med. 2017;05(01):26-37.

22. Menz HB, Dufour AB, Riskowski JL, Hillstrom HJ, Hannan MT. Foot posture, foot function and low back pain: The Framingham Foot Study. Rheumatol (United Kingdom). 2013;52(12):2275-82.

23. Menz HB, Dufour AB, Riskowski JL,
Hillstrom HJ, Hannan MT. Original article Foot posture, foot function and low back pain: the Framingham Foot Study. Rheumoatology. 2013;2275-82.

24. Fan Y, Fan Y, Li Z, Lv C, Luo D. Natural Gaits of the Non-Pathological Flat Foot and High-Arched Foot. PLoS One. 2011;6(3):1-5.

25. Pauk J, Griškevičius J. Ground reaction force and support moment in typical and flat-feet children. Mechanika. 2011;17(1):93-6.

26. Farokhmanesh K, Shirzadian T, Mahboubi M, Shahri MN. Effect of foot hyperpronation on lumbar lordosis and thoracic kyphosis in standing position using 3-dimensional ultrasound-based motion analysis system. Glob J Health Sci. 2014;6(5):254-60.

27. Toumanidou T, Noailly J. Musculoskeletal Modeling of the Lumbar Spine to Explore Functional Interactions Between Back Muscle Loads and Intervertebral Disk Multiphysics. Front Bioeng Biotechnol. 2015;3:1-13. 